\title{
Recurring soft tissue Rosai-Dorfman disease
}

Doença de Rosai-Dorfman recorrente das partes moles

Alex Guedes'; Bruno Barreto'; Lara Grimaldi Soares Barreto²; Iguaracyra B. O. Araújo3; Daniel A. Athanazio ${ }^{4 *}$; Paulo R. F. Athanazio ${ }^{5}$

\section{key words abstract}

Sinus histiocytosis

We present a case of a 27-year-old female patient with recurrent soft tissue Rosai-Dorfman disease in the right leg. This report highlights the fact that tumor recurrence may arise in different sites and show

Soft tissue neoplasms rapid growth.

Recurrence

\section{resumo}

Apresentamos o caso de uma paciente de 27 anos com doença de Rosai-Dorfman recorrente das partes moles na perna direita. Esse relato enfatiza que a recorrência tumoral pode-se dar em sítios distintos e exibir rápido crescimento.

\section{unitermos}

Histiocitose sinus

Neoplasias de tecidos

moles

Recidiva

1. MD, Musculoskeletal Cancer Surgery, Hospital Santa Izabel, Salvador.

2. Medical student, Escola Bahiana de Medicina e Saúde Pública (EBMSP).

3. PhD, Department of Anatomic Pathology, Universidade Federal da Bahia (UFBA).

4. MSC, Department of Biointeraction, UFBA.

5. MSC, Department of Anatomic Pathology, UFBA.

This work was presented at the XXVI Brazilian Congress of Pathology, on November 15, 2007, in Bento Conçalves, Brazil.

The work was approved by the ethics committee of Hospital Santa Izabel. The patient gave written consent for publication of this case report (July 17, 2007 - register number CAAE - 0018.0.057.000-07). 


\section{Introduction}

Rosai-Dorfman disease (RDD), or sinus histiocytosis with massive lymphadenopathy, is characterized by massive painless bilateral lymphadenomegaly that typically involves the head and neck chains. This classical presentation includes fever, leukocytosis, elevated erythrosedimentation rate and polyclonal hypergammaglobulinemia. Most cases occur in the first two decades of life, even though any age group may be affected. The morphologic picture of an inflammatory infiltrate rich in lymphocytes, plasma cells and large histiocytes - the latter with occasional figures of emperipolesis (or lymphocytophagocytosis) - is the hallmark of the disease ${ }^{(6)}$.

The extranodal involvement in RDD has been reported in a wide range of organs, being skin and nasal sinuses the most affected. In the largest series of RDD cases, 43\% (500 patients) had extranodal disease, while only 13 patients had the typical morphologic picture of soft tissue RDD without detectable lymphadenopathy(2). While nodal disease is classified as an inflammatory/hyperplasic disorder which usually undergoes spontaneous regression, extranodal RDD natural history is associated with indolent growth and recurrences along years or decades ${ }^{(6)}$. Thus, soft tissue RDD has been recognized as a distinct clinicopathologic entity ${ }^{(2,5)}$. We report a case of extranodal RDD restricted to soft tissue of the posterior leg and discuss clinicopathologic findings with the available literature.

\section{Case report and discussion}

A 27-year-old female patient presented with a 1.8-cm superficial, firm mass in the upper third of the posterior right leg subcutaneous tissue. The patient noted the nodule seven months before surgical biopsy and reported additional growth in the last month. At physical examination and imaging, the nodule was firm and exhibited no adherences to deep tissues (Figure 1). After histopathology report suggestive of extranodal RDD, the patient underwent tumor excision presenting two local recurrences within two months. On the second recurrent tumor resection, the surgical specimen exhibited an additional $0.4-\mathrm{cm}$ nodule in a different site (intermediate third) in the posterior right leg. After a new surgical resection, a recurrent tumor grew rapidly reaching $4 \mathrm{~cm}$ within two months in the intermediate third of the posterior right leg. A fourth surgical procedure of extended skin and subcutaneous tissue removal was performed with closure by second intention due to insufficient borders.

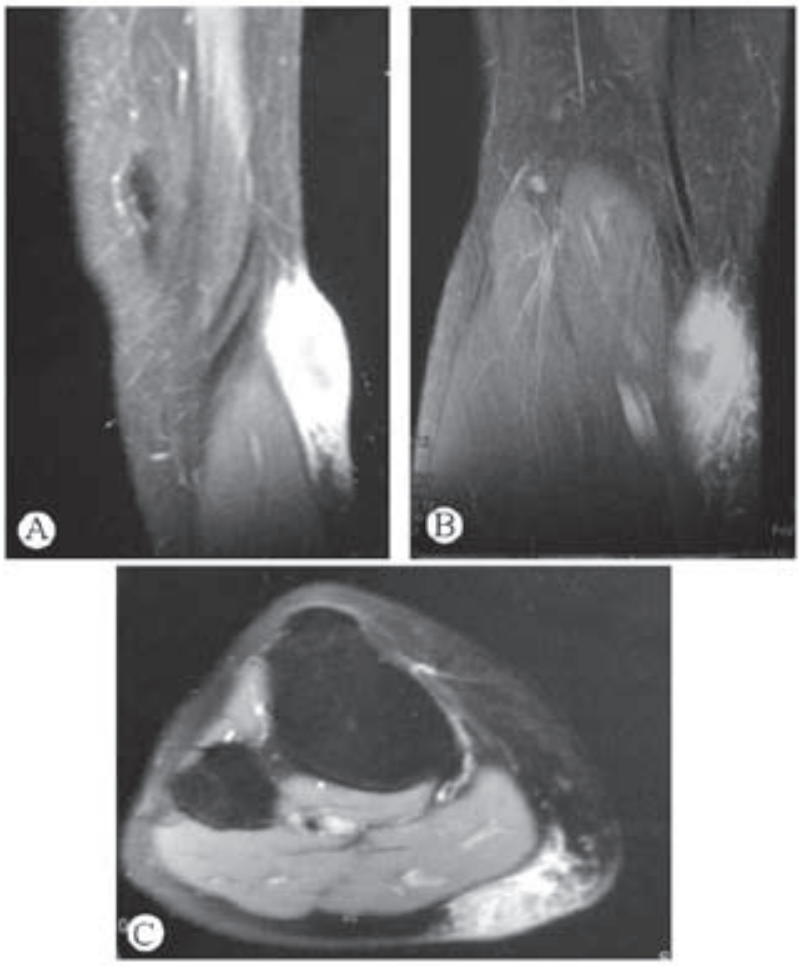

Figure 1 - Fat suppressed contrast-enhanced T1-weighted magnetic resonance imaging of the posterior leg. Expansive subcutaneous mass adjacent to medial gastrocnemius

The first biopsy revealed a 1.8-cm nodule that exhibited a yellowish gross appearance with elastic consistency. Microscopically, a chronic inflammatory infiltrate of lymphocytes and plasma cells predominated with formation of lymphoid aggregates (Figure 2). Large histiocytes with pale cytoplasm were a common finding with sparse areas of aggregation, and suggestive figures of emperipolesis were noted. The diagnosis of RDD was suggested while immunohistochemistry was recommended to support a definitive diagnosis. By the time of the first biopsy, immunohistochemistry at a reference laboratory supported that diagnosis based on expression of S-100 and CD68, while no reactivity was detected of CD15, CD30, pancytokeratin and smooth muscle actin. The proliferative index among reactive cells was $10 \%$. The second biopsy, from recurring $1.5-\mathrm{cm}$ tumor of posterior right leg, was grossly white and firm, exhibiting the same histological pattern with definitive figures of emperipolesis (Figure 3). The third exam included a $2-\mathrm{cm}$ nodule and a $0.4-\mathrm{cm}$ small satellite lesion indistinguishable from the second biopsy gross and microscopically, thus confirming the diagnosis of extranodal RDD. The fourth exam confirmed the recurrent tumor. S100 expression in histiocytes is illustrated in Figure 4. 


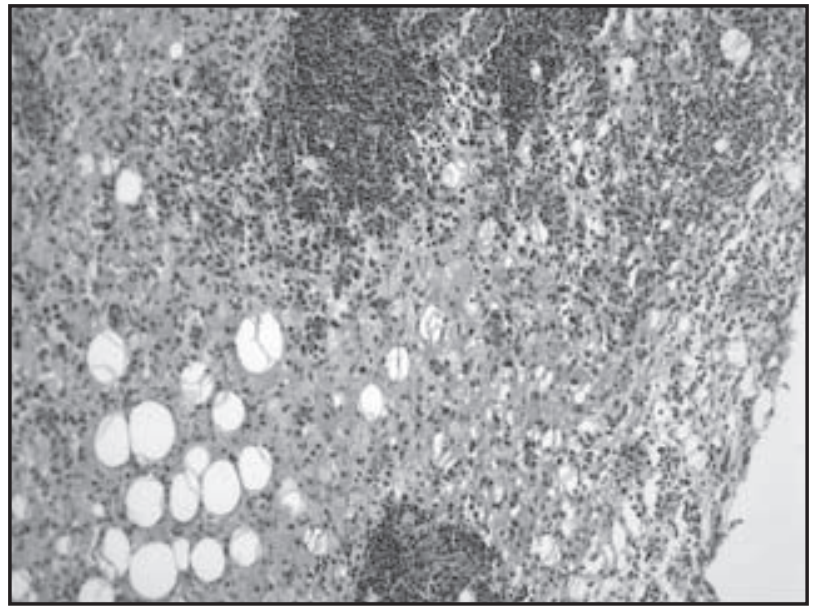

Figure 2-Chronic inflammatory infiltrate with predominance of histiocytes and sparsely distributed lymphoid aggregates (HE 200x magnification)

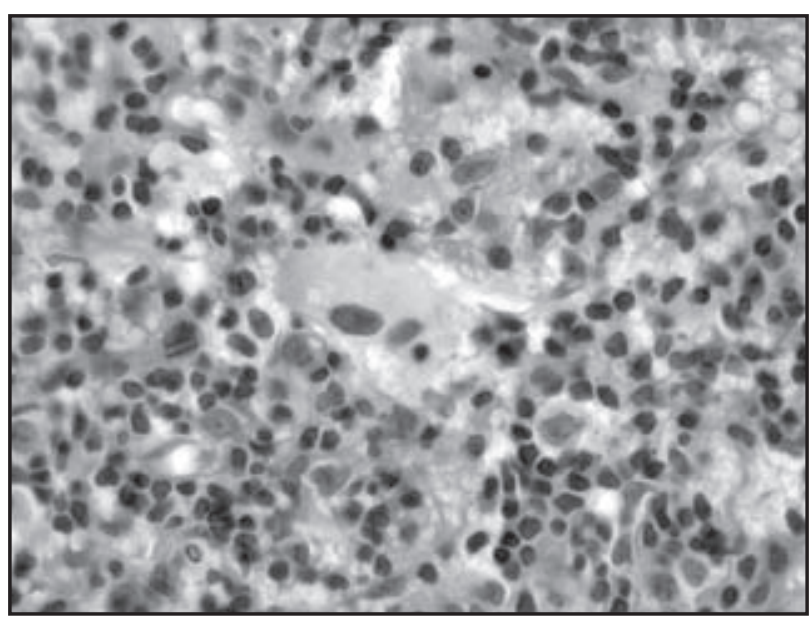

Figure 3 - Two images of emperipolesis (HE 1,000x magnification)

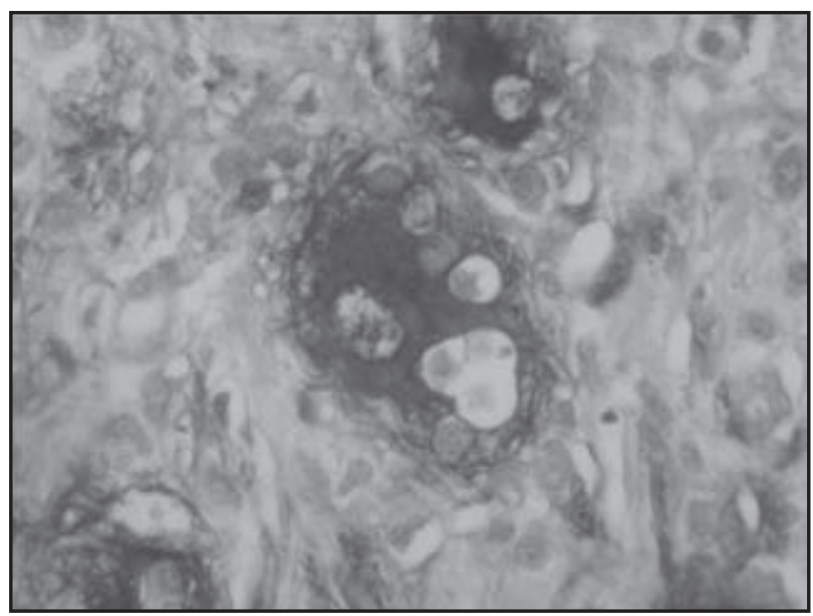

Figure 4 - S-100 expression in a large histiocyte with emperipolesis (anti-S100 antibody, DAKO, streptavidin-peroxidase conjugate, 1,000x magnification)

Extranodal RDD restricted to soft tissues is rare. In the largest series of RDD cases, 13 cases of soft tissue RDD lacked lymph node involvement, while only five cases had solitary lesions ${ }^{(2)}$. A retrospective study of Armed
Forced Institute of Pathology, Washington D.C., United States, described 17 cases of soft tissue involvement of RDD in which 13 lacked lymphadenopathy ${ }^{(5)}$. The clinicopathologic description of a typical case is a slow growing mass unrelated to pain or tenderness while histological findings may be less specific than in nodal counterparts. Fusiform histiocytes, vague storiform pattern, deposits of thin collagen fibers and inconspicuous emperipolesis are frequent observations in soft tissue $\operatorname{RDD}^{(2,5)}$. The diagnosis of RDD is generally made on histological grounds, while immunohistochemistry may be useful in less specific morphological pictures. Reactivity of S-100 protein and histiocytic/lisosomal markers (CD68, lisozime, alpha-1antitrypsin, and alpha-1-antichymotrypsin) are common features, although not required for case confirmation ${ }^{(5)}$. In the present case, large polygonal histiocytes with pale cytoplasm and vesicular nuclei were observed since the first biopsy, while definitive images of emperipolesis were detected in the second and third biopsies.

Soft tissue RDD presentation may be obscured by nonspecific features, leading to common misdiagnosis as inflammatory pseudotumor, fibrohistiocytic disorders or sarcomas. Recent reports highlight the overlapping morphology between some cases of soft tissue RDD and inflammatory pseudotumor ${ }^{(3,7)}$. In one case report, multiple subcutaneous chest and upper limb nodules were originally diagnosed as inflammatory pseudotumor, while paranasal sinuses masses were concluded to be compatible with chronic sinusitis. Again, the attention to large histiocytic cells and emperipolesis and consistent immunophenotype allowed the correct diagnosis ${ }^{(7)}$.

In regard to its natural behavior, soft tissue RDD has been described in largest series as a slow growing processes ${ }^{(2,7)}$ which was recently exemplified by bilateral orbital masses causing exophthalmos for seven years ${ }^{(9)}$. Recurrence is common among soft tissue RDD without lymph node involvement, as exemplified by 7/13 (54\%) recurring tumors after local excision in the large series ${ }^{(5)}$. One report highlights the striking recurrence potential in a case of abdominal wall RDD requiring five reexcisions in 12 years ${ }^{(4)}$. In a case report similar to the present case, a 40-year-old female patient with two distinct nodules in posterolateral right thigh developed a new nodule in left thigh within one year after surgical resection ${ }^{(8)}$. Whenever feasible, wide surgical margins should be performed $^{(1,5)}$ as chemotherapy has not proven to be useful $^{(5,9)}$. 
Our case highlights the importance to include extranodal RDD as a differential diagnosis of inflammatory and fibrohistiocytic soft tissue lesions. It provides additional evidence of the recurrence potential of such disorder and emergence of new sites after surgical excision. The rapid recurrent growth (4 $\mathrm{cm}$ within two months) was an unexpected observation. Attention should be paid to recognize this entity, and more clinicopathologic reports are needed to clarify the behavior and the morphologic spectrum of soft tissue RDD.

\section{Acknowledgements}

We thank Dr. Antônio Nascimento for reviewing the slides.

\section{References}

1. CHENG, S. P.; JENG, K. S.; LIU, C. L. Subcutaneous Rosai-Dorfman disease: is surgical excision justified? J Eur Acad Dermatol Venereol, v. 19, n. 6, p. 747-50, 2005.

2. FOUCAR, E.; ROSAI, J.; DORFMAN, R. Sinus histiocytosis with massive lymphadenopathy (Rosai-Dorfman disease): review of the entity. Semin Diagn Pathol, v. 7, n. 1, p. 19-73, 1990.

3. GOVENDER, D.; CHETTY, R. Inflammatory pseudotumour and Rosai-Dorfman disease of soft tissue: a histological continuum? J Clin Pathol, v. 50, n. 1, p. 79-81, 1997.

4. LEVINE, E. A.; LANDRY, M. M. Rosai-Dorfman disease of soft tissue. Surgery, v. 115, n. 5, p. 650-2, 1994.

5. MONTGOMERY, E. A.; MEIS, J. M.; FRIZZERA, G. Rosai-
Dorfman disease of soft tissue. Am J Surg Pathol, v. 16, n. 2, p. 122-9, 1992.

6. ROSAI, J. Lymph nodes. In: ROSAI, J. Rosai and Ackerman's Surgical Pathology. $9^{\text {th }}$ ed. Milan: Mosby, 2004; Cap 21; p. 1911-3.

7. VEINOT, J. P.; EIDUS, L.; JABI, M. Soft tissue Rosai-Dorfman disease mimicking inflammatory pseudotumor: a diagnostic pitfall. Pathology, v. 30, n. 1, p. 14-6, 1998.

8. YOUNG, P. M. et al. Rosai-Dorfman disease presenting as multiple soft tissue masses. Skeletal Radiol, v. 34, n. 10, p. 665-9, 2005.

9. ZANNOLLI, R. et al. Pathological case of the month. Multifocal Rosai-Dorfman disease of soft tissue. Arch Pediatr Adolesc Med, v. 153, n. 11, p. 1199-2000, 1999. 